\title{
The Influence of Parental Guidance, Group of Peers, School Promotion, and Career Information on Course Preference Decision Class X SMK Muhammadiyah in Bantul
}

\author{
Siska Pujilestari *, Muhammad Sayuti, Fatwa Tentama \\ Email : siska.mudaba@gmail.com* \\ *: coresponndensing author \\ Universitas Ahmad Dahlan, Jl. Pramuka No. 42, Pandeyan, Umbulharjo, Yogyakarta, Indonesia;
}

ARTICLE INFO

Article history

Received Apr 18, 2020

Revised May 21, 2021

Accepted May 31, 2021

Keywords

Course Preference Decision

Parental Guidance

Peers

Retention

Promotion

Career Information
ABSTRACT

The purpose of the study was to analyze the influence of parental guidance, peer group, school promotion, and career information on course preference decision. This study applied a mixed-method with quantitative (multiple regression) followed by the qualitative stage. The quantitative analysis technique is done by a regression test and continued with qualitative. The results showed that partially and simultaneously, the variables of parental guidance, peer groups, school promotion, and career information affected the decision making in choosing the competency of students of SMK Muhammadiyah in Bantul. Career information factors of $12.98 \%$ most influence students' decision making in choosing expertise competencies. School promotion contributed $8.20 \%$ of the decision. The peer factor contributes to $4.78 \%$ of the students' choices. The last of these factors was parental guidance, which provided $4.43 \%$.

This is an open access article under the CC-BY-SA license.

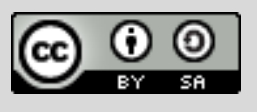

\section{Introduction}

National education is the foundation for every nation, especially for the Indonesian government, which is undergoing development, especially national development in the field of education, with efforts to educate the nation's life and improve the quality of Indonesian people in realizing an advanced society. One of the lines of school education is vocational education. Vocational Secondary School (Vocational School) is one of the secondary schools that strives to provide education with a variety of skills programs that are tailored to the needs of the job market and seeks to improve the quality of graduates so that later they can be useful and engage in the world of work.

Muhammadiyah Vocational School in Bantul Regency consists of Muhammadiyah 1 Bambanglipuro Vocational School, Muhammadiyah 1 Bantul Vocational School, Imogiri 1 
Muhammadiyah Vocational School, Bantul Muhammadiyah 2 Vocational School, and Kretek Muhammadiyah Vocational School have various competencies in expertise such as Automotive Light Vehicle Engineering, Motorcycle Business Engineering, Audio Visual Engineering, Clothing, Computer, and Network Engineering, Accounting, Agricultural Product Processing Engineering, Automation, and Office Governance, Online Business and Marketing, Sharia Banking, Software Engineering, and Multimedia. The diversity of expertise competencies possessed by Muhammadiyah Vocational Schools in Bantul attracts graduates of junior high schools to enroll in these schools. But this can confuse students because of ignorance about how later after they choose and undergo a competency learning skill.

The selection of expertise competencies that match the interests and abilities of students is not natural because there are various considerations before determining the skill of the expertise to be chosen. If students select expertise competencies, not with their interests and abilities, there will most likely be failures such as not being able to follow their learning not as expected or finding it challenging to participate in education because it is not developing their abilities and skills (Putra, 2019).

Psychologically junior high school students are at a stage of adolescence that is still unstable affected by various things in choosing competency skills in Vocational High Schools. The decision to adopt is complex because it involves many aspects of its implementation (Gusdiandika \& Sinduwiatmo, 2012). Errors in choosing expertise competencies can occur when students choose expertise competencies that are influenced by external factors besides their interests and talents. These external factors include parental guidance factors, peer group factors, school promotion factors, and career information factors.

Article 7 of Law Number 20 of 2003 states that parents have the right to participate in selecting educational units and obtain information about the development of their children's education. Parents play an essential role in directing their children to be useful people both for themselves and their families and society in general. The interest of students in choosing expertise competencies can also be influenced by the social environment in which students interact socially. The community environment here, in particular, is the environment of peer groups. The peer group factor in selecting expertise competencies is done by students so that later in the competency expertise they choose already have a known friend.

Another factor that can influence the decision to choose students in determining SMK is one of them is the interest of prospective new students with the promotion carried out by the SMK (Gusdiandika \& Sinduwiatmo, 2012). The development of the school is one source of information that can influence students in making decisions choosing competency expertise that is in vocational schools. The promotion will provide information in the form of new knowledge about 
the details of the school details shown through pictures and information. This information will be processed with the experience of both himself and others so that it will determine the assessment of the Muhammadiyah Vocational School in Bantul. If the promotion given by the Muhammadiyah Vocational School in Bantul can attract prospective new students, students will feel happy and satisfied with the Muhammadiyah Vocational School in Bantul so that it will be followed by the decision to choose a school in the Muhammadiyah Vocational School in Bantul.

Apart from that, some factors also influence student decision making in choosing vocational competency, namely career information. Vocational School is a vocational school, students who decide Vocational School certainly have the desire to work after graduating from school; therefore students must choose competency skills that are in accordance with their abilities also following the changing times, for that student must have a variety of information about careers that have job opportunities or opportunities much later on from the competencies of the chosen skills. An understanding of work will provide more information to students so that it can be used as a basis for making career decisions (Lestari \& Supriyo, 2016). Job prospects and high income can be one of the considerations for interested people to choose a major in a particular Vocational School.

Based on these descriptions, the authors are interested in expressing parental guidance, peer groups, school promotion, and career information, which can influence students in determining their choice to choose competency skills in SMK.

\section{Method}

This research is mixed-method research. The mixed-method is a combination of qualitative and quantitative research in a study (Creswell, 2015). The method used is explanatory sequential mixed methods. The variables in this study consisted of four kinds of independent variables, consisting of parental guidance (X1), Peer group (X2), School promotion (X3), and career information(X4); and the dependent variable is the decision making to choose expertise competency (Y). Population selected was all 10th-grade students of SMK Muhammadiyah in Bantul as many as 1067 students. The sample in this study was 446 students. An example in conducting the interview was done after knowing which variables would be more significant in influencing students' decision to choose expertise competencies.

This research uses mixed-method research by combining two existing forms of research, namely, quantitative research and qualitative research. This research is a type of Ex Post Facto design research in which there is no manipulation of treatment of the independent variables. Ex post facto study examines what has happened to the subject. Ex post facto means "after the fact" because research is done after an event has occurred, this research is research tracing back to an event or an event and then trace back to find out the factors that can cause the incident. This research was conducted after students chose expertise competencies, then find out whether 
parental guidance factors, peer groups, school promotions, and career information influence when students want expertise competencies. In this study, the quantitative method is carried out in analyzing data using numerical data or numbers processed by statistical purposes, after obtaining the results, then described by describing conclusions based on the numbers prepared by the analytical method. A qualitative approach is carried out after getting the results of which variable is more significant, which influences the selection of competencies, carried out an analysis of qualitative approaches using descriptive methods. In the implementation, interviews will be conducted related to more significant variables affecting students.

The questionnaire method was used to determine the effect of parental guidance, peer groups, school promotion, and career information on decision making to choose the expertise competencies of class $\mathrm{X}$ students of SMK Muhammadiyah in Bantul. In compiling this questionnaire, researchers used a Likert scale. Qualitative data collection techniques using semistructured interview techniques. Using this semi-structured interview, each respondent is asked the same question, and the researcher notes the answer or records it. In this interview process also uses the technique of triangulation of data collection sources. This is used to test the credibility and validity of the data from the results of the interview.

Quantitative Analysis Techniques were performed with a regression test. In the regression test process, there are several steps of analysis, namely: (1) Normality test, This normality test is used to find out whether the data is distributed normally or not. Data is said to be normal if Asymp.Sig (significance level / p) $>0.05$ and data is said to be abnormal if Asymp.Sig (significance level / p) $<0.05$., (2) Linearity Test, This linearity test is used to find out whether each variable is linear or balanced equally. Linear Independent Variables with Dependent Variables, if: Sig. Flinearity $<0.05$ and Sig. Deployment from Linearity> 0.05. If one of them is not met, the data can still be said to be linear. Data is not linear if both are not met, sig in the linearity line $p>0.05$, and sig in the deviation from linearity $\mathrm{p}<0.05$., (3) Multicollinearity Test, Multicollinearity test is a test conducted to ascertain whether, in a regression model, there are intercorrelations or colinearities between independent variables. If the VIF value $<10$, then multicollinearity does not occur, or if the tolerance value $>0.01$ does not occur multicollinearity. This means that the data tested is reliable., (4) Regression Hypothesis Test, This regression hypothesis test is used to see the relationship between variables and also the influence between variables. To see the relationship between variables can be seen from the high $\mathrm{R}$-value and its significance value $\mathrm{p}<0.05$, then the relationship between variables is significant, whereas if the significance value $p<0.01$, then the relationship between variables is very significant. And to see the effect between variables can be seen in the significant value in the coefficient table if $\mathrm{p}<0.05$, then the effect is significant, whereas if the value of $\mathrm{p}<0.01$, then the effect is very significant. 
Qualitative data analysis in this study will use Miles and Huberman data analysis, models. According to (Sugiyono, 2017), activity in the process of analyzing Miles and Huberman's data model is: (1) Data Reduction, In this data reduction process, the researcher explains the results of the interview by summarizing, selecting the main points, focusing on the essential matters, looking for themes and patterns, and removing unnecessary information., (2) Presentation of Data, After the data has been reduced, the next step is to present the data. In qualitative research, the presentation of data will be done in the form of brief descriptions, charts, relationships between categories, etc. By displaying the reduced data, it will be easier to understand what is happening., (3) Verification, The final step in the analysis of qualitative data is drawing conclusions and verification. The outcome in this qualitative research is to be able to answer the problem formulation that was formulated from the beginning or even in the form of new findings that had never before existed. These findings can be in the form of a description or description of an object that was previously still in doubt, become apparent.

\section{Result and Discussion}

\section{Research Question 1}

The hypothesis in this study was tested using multiple linear regression analysis. The results of the regression analysis are presented in Table 1.

Table 1. Research Hypothesis Test Results

\begin{tabular}{lccc}
\hline \multicolumn{1}{c}{ Variable } & $\begin{array}{c}\text { Regression Coefficient } \\
(\boldsymbol{\beta})\end{array}$ & T count & Sig. \\
\hline Parental Guidance & 0,14 & 3,29 & 0,00 \\
Peer & 0,16 & 3,85 & 0,00 \\
School Promotion & 0,22 & 5,20 & 0,00 \\
Career Information & 0,29 & 6,46 & 0,00 \\
\hline \multicolumn{4}{c}{ F count $=48,174$} \\
& Significance $=0,000$ & & \\
& R Square $=0,304$ & & \\
\hline
\end{tabular}

The effect of Parental Guidance, Friends, School Promotion and Career Information on Decision Making, shows the results of the analysis of the calculated F value obtained is 48.17 with a significance of 0.00 where the amount is less than 0.05 , meaning the guidance of parents, peers, school promotion, and career information together have a significant effect on student decision making. The amount of $\mathrm{R}$ square value obtained is 0.304 , meaning that the amount of control given by the four independent variables to the dependent variable is $30.39 \%$. Thus, it can be concluded that the hypothesis which states, "There is an effect of parental guidance, peer guidance, school promotion, and career information together with the decision to choose skill competencies in class $\mathrm{X}$ students" is accepted. The results of the calculation show that student decision making in choosing a major is most influenced by career information, namely SE at $12.98 \%$ or SR of $42.70 \%$. Then followed by school promotion to the department with SE $8.20 \%$ or SR $26.98 \%$, peer influence 
with SE $4.78 \%$ or SR $15.75 \%$, and finally parental guidance with SE $4.43 \%$ or SR of $14,57 \%$. Thus, it means that students make a choice of majors based on the much-needed career information so that it is hoped that when they graduate from school they can immediately get a job.

Table 2. The Influence of Each Independent Variable on Bound Variables

\begin{tabular}{ccccc}
\hline Variable & $\begin{array}{c}\text { The } \\
\text { correlation } \\
\text { coefficient (X- } \\
\text { Y) }\end{array}$ & $\begin{array}{c}\text { Regression } \\
\text { Coefficient } \\
\text { ( } \boldsymbol{\beta} \text { ) }\end{array}$ & $\begin{array}{c}\text { Sufficient } \\
\text { Donations } \\
\text { (SE) }\end{array}$ & $\begin{array}{c}\text { Relative } \\
\text { Donations } \\
\text { (SR) }\end{array}$ \\
\hline Parental Guidance & 0,31 & 0,14 & $4,43 \%$ & $14,57 \%$ \\
Peer & 0,30 & 0,16 & $4,78 \%$ & $15,75 \%$ \\
School Promotion & 0,37 & 0,22 & $8,20 \%$ & $26,98 \%$ \\
Career Information & 0,45 & 0,29 & $12,98 \%$ & $42,70 \%$ \\
Total influence & & & $\mathbf{3 0 , 3 9 \%}$ & $\mathbf{1 0 0 , 0 0 \%}$ \\
\hline
\end{tabular}

The results of the analysis on the effect of parental accompaniment on decision making show that the regression coefficient value obtained is positive, which is 0.14 , meaning that the more often parents provide guidance, the stronger the decisions are taken by students to determine the chosen course. The t value obtained is 3.29 with a significance of 0.00 where the value is less than 0.05 , which means that parental guidance has a significant effect on student decision making. Thus, it can be concluded that the hypothesis which states, "There is a significant influence between the parental guidance variable and the decision to choose skill competencies in class X students" is accepted.

The results of the analysis on Peer Influence on Decision Making, show that the regression coefficient value obtained is positive, which is 0.16 , meaning that the more information and invitations from peers about a major, the stronger the decisions are taken by students to determine the courses that are selected. The t value obtained was 3.85 with a significance of 0.00 where the value was less than 0.05 , meaning that peers had a significant influence on student decision making. Thus, it can be concluded that the hypothesis which states, "There is a significant influence between peer variables and the decision to choose skill competencies in class X students" is accepted.

The results of the analysis on the Effect of School Promotion on Decision Making, show that the regression coefficient obtained is positive, namely 0.22 , meaning that the more often schools promote a department, the stronger the decisions taken by students to determine the chosen course. The $t$ value obtained was 5.20 with a significance of 0.00 where the value was less than 0.05 , meaning that school promotion had a significant effect on student decision making. Thus, it can be concluded that the hypothesis which states, 
"There is a significant influence between school promotion variables and the decision to choose skill competencies in class X students" is accepted.

The results of the analysis on the Effect of Career Information on Decision Making, show that the regression coefficient obtained is positive, namely 0.29 , meaning that the more often schools provide information about careers that can be achieved through a department, the stronger the decisions taken by students to determine courses The selected. The t value obtained was 6.46 with a significance of 0.00 where the value was less than 0.05 , meaning that career information had a significant influence on student decision making. Thus, it can be concluded that the hypothesis which states, "There is a significant influence between career information variables and the decision to choose skills competency in class X students" is accepted.

\section{The influence of parental guidance, peer groups, school promotion, and career}

\section{information together on the decision to choose expertise competencies in class $\mathrm{X}$ students} of SMK Muhammadiyah in Bantul.

The decision to select expertise competency in a Vocational School is a thought process of several alternative competency skills or possibilities that best suit student goals. The results showed that parental guidance, peer groups, school promotion, and career information together had a positive effect on the decision to choose competency skills in class X students of SMK Muhammadiyah in Bantul. This shows that if the guidance of parents, peer groups, school promotion, and career information together increases, the decision to choose competency skills in class X students of SMK Muhammadiyah in Bantul will also increase.

The decision to choose expertise competency serves as the first step in student activity before undergoing or entering the life of learning in Vocational Schools. This is in line with Hasan (2002), who explains that the function of decision making as a continuation of problem-solving is as a starting point for all human activities, and functions to be something futuristic or related to the future. Therefore, choosing expertise competency by Muhammadiyah Vocational School students in Bantul requires careful thinking by considering various things, namely the guidance of parents, peer groups, school promotion, and career information because it is related to the future of students after graduating from school. The decision to choose expertise competencies in class $\mathrm{X}$ students of SMK Muhammadiyah in Bantul consists of information considerations, determining alternatives, and decision resolution. The attention of the information made in the decision to choose competency skills in class X students of SMK Muhammadiyah in Bantul can be obtained from friends and family who provide information as a consideration in choosing a major. Students need to consider various details before deciding on a course to be selected to suit their interests 
and job opportunities. Determining choices of majors needs to be adjusted to the strengths and weaknesses of the students and to choose appropriate majors.

The final stage in decision making is the completion of the decision by choosing a department that supports the achievement of the ideals, deciding to enter a vocational school following the ability, and there is confidence in the decisions taken in selecting the department when first registering at the Vocational School. Decisions in choosing majors in SMK require appropriate consideration and selection and assess the impact of the election results because it will be the responsibility of students to learn based on the decisions taken. This is in line with the opinion of Laden (2014) that is the result of a decision that has been made by someone who must be accountable either for himself or for others relating to the decision.

\section{The influence of parental guidance on the decision to choose expertise competencies in class X students of SMK Muhammadiyah in Bantul.}

The advice, in general, aims to help children to get reasonable adjustments in learning situations so that every child can learn efficiently following their abilities and achieve optimal development. Parents are the primary educators in the family for children. Parents have the right to direct children to be useful people both for themselves and their families and society in general. The results showed that parental guidance had a positive effect on the decision to choose competency expertise in class X students of SMK Muhammadiyah in Bantul. This indicates that if the level of parental guidance increases, the decision to select expertise competencies in class $\mathrm{X}$ students of SMK Muhammadiyah in Bantul will also increase. These results are in line with research by Rini (2014), who found that there was the involvement of parents and children in making decisions in choosing education majors. Parent and child involvement can be seen by the close relationship and open dialogue that helps parents and children understand each other's desires and expectations so that decisions made reach mutual understanding. Parents play a role in giving consideration or advice and directing children in the decision-making process.

Parental guidance in directing children to make decisions in choosing expertise competencies in class X students of SMK Muhammadiyah in Bantul can be seen from the advice of parents in this study, namely providing learning facilities, helping to overcome various learning difficulties experienced by children, and providing learning motivation. This is supported by the findings of Itkunminannar (2016) that parental guidance consists of providing learning facilities, providing advice to children, and providing motivation to learn. There are various activities that parents can do in guiding their children to make decisions in choosing competency skills. Parents include motivating children to learn, helping to overcome difficulties in learning, providing facilities or means for learning, supervising children in education, getting to know the problems of children in learning (Walgito, 2010). The results of interviews with students explain that the motivation given 
by parents in choosing competency skills can be in the form of asking questions about the chosen majors, providing support, providing choices, giving approval, giving explanations, giving directions, and not limiting. Parents of SMK Muhammadiyah students in Bantul are trying to give support to motivate their children in learning and in choosing skills competencies by providing a variety of career information by their interests and abilities. As for parents not driving due to various factors originating from families such as not living in one house. Footage of the results of interviews with Muhammadiyah Vocational School students in Bantul.

Parents also provide facilities that support students so that they can make it easy to obtain information and understanding as a consideration in choosing majors at SMK. Facilities provided by parents to help children in finding information and selecting the right majors that are by providing mobile phones, internet access, stationery, and books that support the selection of majors. Parental guidance by helping to overcome various learning difficulties experienced also has a significant role towards class X students of SMK Muhammadiyah in Bantul in deciding on choosing majors. Majors can be done by inviting children to discuss interests and abilities as well as instilling to like and learn well the chosen majors. Parents can be used as the most comfortable place to tell problems and help provide advice when students have difficulty choosing majors. Based on the results of interviews with students explaining that parents help overcome various difficulties, especially in terms of choosing competency, expertise is done by discussing, convincing choices, reminding to learn, giving explanations about majors, and providing solutions to problems faced.

The selection of majors in SMK according to the parents of students of class X SMK Muhammadiyah in Bantul only leaves students with the decision to choose a major, and there are no questionnaires and interviews from schools to students and parents to be ready to carry out learning according to the chosen majors. Suggestions recommended by parents based on the results of interviews that vocational schools should provide assistance, test competencies, interests, and talents to students. Schools should also offer directives through conversations with prospective students and parents.

\section{The influence of peer groups on the decision to choose expertise competencies in class $\mathbf{X}$ students of SMK Muhammadiyah in Bantul.}

Vocational students are in adolescence, which is a transition period from childhood to adulthood and have the need to get along with many people, especially peers. Therefore, the closeness of peers in the development and formation of student identity is important because students can be more spend more time with friends than with family to exchange information about various things, including vocational competency skills. The results showed that peer groups had a positive effect on the decision to choose expertise competencies in class X students of SMK 
Muhammadiyah in Bantul. If the close relationship with peer groups increases, the decision to select expertise competencies in class X students of SMK Muhammadiyah in Bantul will also increase. These results are in line with research by Rini (2014), which explains that there are peers who also play a role as friends to share and also provide choices for majoring in education. The existence of peers is essential for class X students of SMK Muhammadiyah in Bantul. The similarity in various aspects, especially age and status, causes students to feel comfortable when together with peers. This is consistent with Santrock's opinion (2003) that children tend to feel comfortable being with their peers rather than being with adults, even though adults are accepting and understanding. Peers have various functions, according to Susanto (2018), among others, to gain pleasure and to adapt to stress, to problem-solving and acquisition of knowledge, as a basis for establishing more musical forms of relationships, and as a context in which necessary social skills obtained or improved.

Peers in influencing the decision to choose expertise competencies in class X students of SMK Muhammadiyah in Bantul can be seen from the existence of peer interaction, social roles, and openness. This is in line with Fitria et al. (2017) that peer interaction is peer interaction that is held with close friends, interests, and intensity in groups, social roles of individuals when in groups, and social comparison as a process of mutual influence and mutual behavior compete. Interaction between peers that influence the decision to choose expertise competencies in class $\mathrm{X}$ students of SMK Muhammadiyah in Bantul, namely the discussion of majors with school friends and school friends, is constructive in selecting majors with peers. The social role shown by peers is the cooperation in finding information about the vocational majors and giving advice to each other when they have problems choosing professional majors. The results of interviews with students showed that most students of SMK Muhammadiyah in Bantul felt that friends could provide solutions if there were problems in choosing majors, helping one another, and encouraging.

Openness between peers in supporting decision-making in choosing competency skills is demonstrated by exchanging information about the majors at SMK and telling each other the preferred majors. Peer groups, according to Aziz et al. (2015) namely as a learning group that is seen based on the process of relationships or interactions between individuals in the group, and one indicator of the relationship process is the existence of openness. Based on the results of interviews with students explained that students discuss or tell majors in vocational schools that are preferred and selected. 
The effect of school promotion on the decision to choose expertise competencies in class $\mathrm{X}$ students of SMK Muhammadiyah in Bantul.

Development of Muhammadiyah Vocational Schools in Bantul is a variety of activities carried out by schools to communicate school quality, choice of majors and to convince prospective students to choose to study at SMK Muhammadiyah in Bantul. Muhammadiyah Vocational School in Bantul has made various efforts to promote majors to attract prospective students by collaborating with various interested parties or stakeholders, disseminating information through mass media and social media, making presentations directly to SMP/MTs, installing billboards, holding multiple activities such as social services, home visits, competitions, and training. Various promotional efforts undertaken by the Muhammadiyah Vocational School in Bantul involved various parties who assisted in the promotion to run smoothly, namely teachers, employees, students, parents, communities, foundations, and alumni. The results showed that school promotion had a positive effect on the decision to choose expertise competencies in class $\mathrm{X}$ students of SMK Muhammadiyah in Bantul. This indicates that if the level of school promotion increases, the decision to select competency expertise in class X students of SMK Muhammadiyah in Bantul will also increase. The results of Fadjrin and Muhsin's (2017) research showed that there was a positive and significant influence on the partial promotion of school on the interest of students choosing majors. The results of the study by Gusdiandika and Sinduwiatmo (2012) also explained that there was an influence of school promotion activities on the decision of students to choose schools in SMK.

School promotion activities in influencing the choice of expertise competencies in class $\mathrm{X}$ students of SMK Muhammadiyah in Bantul can be seen from the ability to provide information, advertising, and marketing. The ability to provide information in school promotion is demonstrated by providing clear, easy to understand, and complete information about majors in SMK. Some promotional objectives, according to Kotler and Keller (2009), inform, persuade, and remind. Based on the results of interviews with students explaining that SMKs provide clarity of the information to students about the various competency skills offered.

Muhammadiyah Vocational School in Bantul advertises schools using promotional media (banners, billboards, banners, brochures), through social media, through radio, making presentations to SMP/MTs, conducting skills training in SMP/MTs, leading social services in the community or recitation, give prizes/scholarships to prospective students, do door to door to prospective students' homes, invite guardians of potential junior high school/MTs alumni to vocational schools, provide free services/services, and so on. Based on the results of interviews with students explained that the expertise competency advertisements made by SMK are engaging, informative, clear, and easy to understand. The role of marketing is as a consideration 
for the selection of majors by Muhammadiyah Vocational School students in Bantul because of presentations that are easily recognized from SMKs who come to SMP / MTs. Gusdiandika \& Sinduwiatmo (2012) explained that in direct marketing, given the ease, presentation, and question and answer. Based on the results of interviews with students told that the performances of vocational competencies held by vocational schools were engaging, easy to understand, and transparent. But not all junior high schools were visited by vocational high schools that held presentations to promote the choice of competency skills or majors. Based on the results of interviews with the Principal explained that the majority of promotional activities carried out went well but needed evaluation. An evaluation was conducted to find out the strengths and weaknesses as well as the best solution in promoting majors at the Muhammadiyah Vocational School in Bantul.

\section{The influence of career information on the decision to choose expertise competencies in class X students of SMK Muhammadiyah in Bantul.}

Career information is information, facts, and ideas that include information about the various fields of work, work activities, and competencies that must be possessed. The results of the research show that career information has a positive effect on the decision to choose expertise competencies in class X students of SMK Muhammadiyah in Bantul. Career information is essential for students as a reference material that provides knowledge and understanding of careers so that it can be used as consideration for decision making choosing majors in SMK. The career information that supports the decision to select competency skills in class X students of SMK Muhammadiyah in Bantul is the knowledge that gives career understanding, alternative career choices, evaluation of alternative career choices. Career information is needed by students. Based on the results of interviews with students shows that there are still some students who do not understand the skills required for the labor market. The skills needed by students in the labor market, according to Teachers BK Muhammadiyah Junior High School in Bantul, namely expertise in the use of current technology following the Industrial Revolution 4 program including mastering the use of computers both software and hardware. The skill is supported by increased creativity developed through UI learning at school so that graduates are ready to enter the workforce.

Career information provides knowledge about various careers and expertise competencies needed so that it can be used as a consideration of multiple alternative career choices that are appropriate to the major The BK Junior High School teacher explained that it is hoped that students who take vocational education through consideration of alternative career choices can open insight into the selection of majors that are more in line with their interests, talents and career choices after graduating from SMK. Career choice alternatives are a list of possible career 
choices made by grade X students of SMK Muhammadiyah in Bantul. The career information that provides knowledge about career choice alternatives that is job information that can be used to determine alternative job options that are suitable majors chosen and job vacancy information can explain job opportunities that match the majors in SMK. Based on the results of interviews with Muhammadiyah Vocational School, students in Bantul shows that career information students consider various alternative career choices that fit the chosen skill competencies. Following the results of interviews with Muhammadiyah Vocational School students in Bantul.

Activities in assessing career information can also be done by evaluating alternative career choices. Based on the interview results, it is explained that the evaluation conducted by students after knowing alternative career choices related to the selection of skills competency in vocational high schools is done by asking parents, choosing according to their abilities and desires. , and learn and understand majors. Important student career information in the decision to choose expertise competencies in class X students of SMK Muhammadiyah in Bantul because various things can be used as consideration. According to Dami \& Waluwandja (2017), career information services are related to the development of the world of work, the conditions of the world of work, information on various types of tertiary institutions associated with the world of work, as well as gaining selfunderstanding that are interests, abilities, skills, personality, attitudes, and values.

\section{Large factors that influence students to determine the decision to choose competency expertise.}

Factors of parental guidance, peer groups, school promotion, and career information jointly influence students to assess the choice to select expertise competence by $30.39 \%$. In comparison, the remaining $69.61 \%$ is influenced by other variables not examined in this study. Sequentially from the factors that have the most significant influence on the smallest factors are career information, school promotion, peer groups, and parental guidance. Career information has an impact on the decision to choose expertise competencies that is equal to $12.98 \%$. School promotion influences the choice to select the expertise competency that is equal to $8,20 \%$. Peers have an influence on the decision to choose expertise competencies that is equal to $4.78 \%$. Parental guidance has an impact on the decision to select the expertise competency that is equal to $4.43 \%$.

\section{The reason one factor is more influential than the others in contributing to the decision to choose expertise competencies in class X students of SMK Muhammadiyah in Bantul.}

The factor that has the most significant influence in providing to the decision to select expertise competencies in class X students of SMK Muhammadiyah in Bantul is career information. The results are supported by interviews with students, which show that students consider information from various sources related to the chosen competency expertise. 
Career information is the most influential factor because it is an essential factor as a reference that supports decisions in choosing majors for the future of students. The availability of career information relevant to the skills possessed by students can support in facing difficulties in making decisions in choosing expertise competencies at SMK Muhammadiyah in Bantul. This is in line with Hidayati's opinion (2015), which explains that problems in making decisions can be avoided when students have an adequate amount of information about matters related to the world of his career. Career information is one of the knowledge that contributes to students by explaining the description of Vocational Schools and arousing students' interest to enter the Muhammadiyah Vocational School in Bantul. If the career information possessed by students is low, then it can cause low career maturity of students needed in making career choice decisions. This is in line with Kamil \& Daniati (2016) which states that the causes of the low career maturity of students are indicated by the low number of students planning a career, the small number of students seeking career information, lack of knowledge about making career decisions, lack of knowledge about the world of work, lack of understanding of preferred occupational groups and the profound realization of students' career decisions. Career information is not only a factual object but as the ability of a psychological process to transform that information, which is associated with future choices and life goals. The content of career information is a career service that seeks to help individuals to plan, decide, and plan for the future they will live (Hidayati, 2015).

\section{Student opinion is related to the tendency of decision making to choose the competence of} class X students.

Class X students of SMK Muhammadiyah students in Bantul have different ways of making decisions in choosing expertise competencies at SMK. The decision-making tendency to select the expertise competency of Grade X students of SMK Muhammadiyah Vocational School in Bantul can be based on specific criteria according to the conditions of the students and how students can determine competency skills. The criteria used to select choices of expertise competency based on the results of interviews with students include conformity to expertise or ability, interest, ease of finding work after graduating from a vocational school, and following labor market needs. Ways to determine expertise competencies based on interviews with students of Muhammadiyah Vocational Schools in Bantul, namely by looking at the abilities, desires, talents, discussing with parents and friends, and looking for information about the chosen majors. This is in line with Rahmayu \& Serli (2018), which explains that prospective students are expected to be able to assess their interests, talents, and abilities so as not to choose the wrong major to be taken. 


\section{Conclusion}

Based on the results of research and discussion, the main findings of this study can be concluded as follows: (1) Parental guidance, peers, school promotion, and career information together have a significant effect on decision making of class X students of SMK Muhammadiyah Bantul in choosing expertise competencies. (2) Parental guidance has a positive and significant influence on decision making of class X students of SMK Muhammadiyah Bantul in choosing expertise competencies. (3) Peers have a positive and significant influence on decision making of class $\mathrm{X}$ students of SMK Muhammadiyah Bantul in choosing expertise competencies. (4) School promotion has a positive and significant influence on decision making of class X students of SMK Muhammadiyah Bantul in choosing expertise competencies. (5) Career information has a positive and significant influence on decision making of class X students of SMK Muhammadiyah Bantul in choosing expertise competencies. (6) Factors of parental guidance, peer groups, school promotion, and career information jointly influence students to determine the decision to choose competency skills by $30.39 \%$. In sequence, the factors that have the biggest to the smallest influence are career information, school promotion, peer groups, and parental guidance. (7) Career information factor has the most significant influence in contributing to the decision to choose competency skills in class X students of SMK Muhammadiyah in Bantul because students need consideration of information from various sources as a reference that supports the decision and supports in facing difficulties in choosing competency skills in SMK. (8) The tendency for decision making in choosing expertise competencies can be based on specific criteria, namely suitability with expertise or ability, interest, ease of finding work after graduating from a vocational school, and following labor market needs. 


\section{References}

Aziz, M. A., Tarmedi, E., \& Untung, S. H. (2015). Hubungan antara kelompok teman sebaya dengan prestasi belajar siswa SMKN. Journal of Mechanical Engineering Education, 2(2), 233-238.

Creswell, J. (2015). Riset pendidikan: Perencanaan, pelaksanaan, dan evaluasi riset kualitatif dan kuantitatif. Yogyakarta: Pustaka pelajar.

Dami, Z.A., \& Waluwandja, P.A. (2017). Pengaruh layanan informasi karir terhadap kemandirian pemilihan karir. Jurnal Cakrawala, Tahun VI, Nomor 12, 1145-1156.

Depdiknas. (2003). Undang-undang RI No.20 tahun 2003. Tentang Sistem Pendidikan Nasional.

Fadjrin, M. A., \& Muhsin. (2017). Pengaruh lokasi sekolah, promosi sekolah, persepsi dan teman sebaya terhadap minat siswa memilih jurusan. Economic Education Analysis Journal, 6(2), 352-364.

Fitria, R. D., Muswardi, M., \& Mayasari, S. (2017). Pengaruh pergaulan teman sebaya terhadap motivasi belajar siswa. ALIBKIN (Jurnal Bimbingan Konseling), 5(4), 53-67.

Gusdiandika, R., \& Sinduwiatmo, K. (2012). Pengaruh promosi sekolah terhadap keputusan siswa dalam pemilihan smk sepuluh nopember sidoarjo. KANAL, 1(1), 28-37.

Hasan, M. I. (2002). Pokok-pokok materi teori pengambilan keputusan. Bogor: Ghalia Indonesia.

Hidayati, R. (2015). Layanan Informasi Karir Membantu Peserta Didik Dalam Meningkatkan Pemahaman Karir. Jurnal Konseling GUSJIGANG, 1 (1).

Itkunminannar, N. (2016). Hubungan bimbingan orang tua dan guru dengan tanggung jawab belajar siswa. Jurnal Pendidikan Guru Sekolah Dasar Edisi 11 Tahun ke-5.

Kamil, B., \& Daniati.(2016). Layanan Informasi Karir Dalam Meningkatkan Kematangan Karir Pada Peserta Didik Kelas X Di Sekolah Madrasah Aliyah Qudsiyah Kotabumi Lampung Utara Tahun Pelajaran 2016/2017.Jurnal Bimbingan dan Konseling, 3(2), 245-258.

Kotler, P., \& Keller, K. L. (2009). Manajemen pemasaran. Jakarta: Erlangga.

Laden, M. (2014). Peranan Dukungan Orang Tua dengan Keputusan Memilih Jurusan Di Perguruan Tinggi Pada Siswa Kelas XII SMA Katolik W.R. Soepratman Samarina. eJournal Psikologi, 2(3), 327-337.

Lestari, D., \& Supriyo.(2016). Kontribusi minat jurusan, kualitas layanan informasi karir, dan pemahaman karir terhadap kemampuan mengambil keputusan karir. Jurnal Bimbingan Konseling, 5(1), 47-54.

Putra, R. S. (2019). Faktor-faktor yang mempengaruhi minat pemilihan kompetensi keahlian akuntansi di SMK N 6 Surakarta. Publikasi Ilmiah. Universitas Muhammadiyah Surakarta.

Rahmayu, M., \& Serli, R. K. (2018). Sistem pendukung keputusan pemilihan jurusan pada smk putra nusantara jakarta menggunakan metode analytical hierarchy process (ahp). 
Simetris: Jurnal Teknik Mesin, Elektro dan Ilmu Komputer, vol. 9(1), ISSN: 2252-4983.

Rini, Y. S. (2014). Komunikais orang tua-anak dalam pengambilan keputusan pendidikan. Interaksi, 3, 112-122.

Santrock, W. J. (2003). Adolescense: Perkembangan remaja. Jakarta: Erlangga.

Susanto, A. (2018). Bimbingan dan konseling di sekolah: Konsep, Teori, dan Aplikasinya. Jakarta: Prenadamedia Grup.

Walgito, B. (2010). Bimbingan Dan Konseling (Studi Dan Karier). Yogyakarta: Andi Offset. 